\title{
Characterization of Vibrio anguillarum Strains Isolated from Diseased Fish in Finland
}

\author{
By T. Tiainen ${ }^{\prime \#}$, J. L. Larsen ${ }^{2}$ and S. Pelkonen ${ }^{I}$
}

'National Veterinary and Food Research Institute, Regional Laboratory of Kuopio, Finland, and ${ }^{2}$ Department of Veterinary Microbiology, Laboratory of Fish Diseases, Royal Veterinary and Agricultural University, Frederiksberg, Denmark.

Tiainen, T., J. L. Larsen and S. Pelkonen: Characterization of Vibrio aguillarum strains isolated from diseased fish in Finland. Acta vet. scand. 1994, 35, 355-362. - Characterization of $V$. anguillarum strains $(\mathrm{n}=109)$ isolated from diseased salmonids was performed. Eight $\mathrm{O}$ serovars were found among the strains. Serovar O1 was predominant $(90 \%$ ), while serovars $\mathrm{O} 2, \mathrm{O} 3, \mathrm{O}, \mathrm{O} 8, \mathrm{O}$, and a new serovar Va NT2, were represented by 1 or 2 strains. Two strains remained non-typeable. One of these was crossreactive with several antisera, but had a LPS profile identical to that of serovar O8. All serovars showed specific LPS profiles. All but 1 of the O1 strains had a plasmid comparable in size to the pJM1 virulence plasmid, while plasmids of different sizes were found in $\mathrm{O} 2$, Va NT2 and the non-typeable strains. Apart from a single strain resistant to tetracycline, all the strains were sensitive to oxolinic acid, tetracycline, and trimethoprim-sulfonamides. By their biochemical and antigenic properties strains causing vibriosis among salmonids in Finland closely resemble Scandinavian strains. Predominance of the serovars $\mathrm{O} 1$ and $\mathrm{O} 2$ suggests that commercial vaccines containing these serovars should afford sufficient protection against vibriosis in Finland.

salmonids; serovar; plasmid; lipopolysaccharide; biochemistry; susceptibility to antibiotics.

\section{Introduction}

Vibriosis is one of the most important bacterial diseases in aquaculture (Austin \& Austin 1987). Mortalities, together with retarded growth, bad slaughter quality and treatment with antibiotics influence the economy of fish farming. In Europe vibriosis is mainly caused by Vibrio anguillarum, while in North America and Japan Vibrio ordalii is also associated with the disease. Other Vibrio species and recently $V$. anguillarum related (VAR) organisms have also been found as fish pathogens

\# Present address: Royal Veterinary and Agricultural University, Department of Veterinary Microbiology, Laboratory of Fish Diseases, Bülowsvej 13, DK-1870 Frederiksberg C, Denmark.
(Colwell \& Grimes 1984, Myhr et al. 1991, Pazos et al. 1993).

$V$. anguillarum strains have traditionally been divided into 10 serovars according to their $\mathrm{O}$ antigen structure (Sørensen \& Larsen 1986), but recently additional serovars have been proposed (Pedersen et al. 1993). Strains belonging to serovars $\mathrm{O} 1$ and $\mathrm{O} 2$, and to a lesser extent $\mathrm{O} 3$ are commonly associated with vibriosis, while strains in the other serovars or non-typeable strains are opportunistic pathogens, i.e they are present in the aquatic environment but only rarely cause disease outbreaks (Muroga et al. 1986, Sørensen \& Larsen 1986, Larsen et al. 1988, Larsen et al. 1994). 
Vaccines against the most common causative agents of vibriosis, $V$. anguillarum $\mathrm{O} 1$ and $\mathrm{O} 2$ and $V$. ordalii, are available, and are widely used in Finnish fish farming. However, outbreaks of vibriosis in vaccinated fish are reported in Finland as well as in Canada and Norway (Paterson et al. 1989, Myhr et al. 1991). The failures in vaccination have raised the question whether commercial vaccines are unsuitable against vibriosis in Finland or whether the vaccination methods are improper. To address this point, and to understand more about the epidemiology of $V$. anguillarum infection in Finland, we have characterized strains isolated from cases of vibriosis in salmonid fish.

\section{Materials and methods}

\section{Bacterial strains}

A total of $109 \mathrm{~V}$. anguillarum strains isolated from diseased fish were included in the study. The strains were isolated during 1988-91 from 3 different fish species by The National Veterinary and Food Research Institute, and The University of Åbo Academy (Table 1). The strains were stored at $-80{ }^{\circ} \mathrm{C}$ until analysis. The isolates were initially identified as $V$. anguillarum from their colony morphology, hemolysis, oxidase and catalase reactions, Gram-staining, motility, and utilization of glucose. The identity of the strains was confirmed by susceptibility to the vibriostatic agent 2,4diamino-6,7-di-isopropyl pteridine, 0/129 (Neo-sensitabs $10 \mu \mathrm{g}, \mathrm{A} / \mathrm{S}$ Rosco, Taastrup, Denmark) and by the symptoms in the fish.

\section{Serogrouping}

All strains were serogrouped by the slide agglutination test using polyclonal $\mathrm{O}$-antisera produced in rabbits against $V$. anguillarum serovars O1-O10 (Sørensen \& Larsen 1986), as well as 5 previously non-typeable strains (Va NT1-5) (Pedersen et al. 1993). Serovar O2 strains were devided into subgroups $\mathrm{O} 2 \mathrm{a}$ and O2b with absorbed antisera according to Larsen et al. 1994. The preparation of antigens, production of antisera, preparation of samples for agglutination and slide agglutination test were performed as described by $S \varnothing$ rensen \& Larsen (1986).

\section{Lipopolysaccharide (LPS) profiles}

Proteinase-K treated samples were prepared using a method modified from Hitchcock \& Brown (1983). Overnight bacterial cultures were harvested with $1 \mathrm{ml}$ phosphate-buffered saline ( $\mathrm{pH} \mathrm{7.3),} \mathrm{incubated} \mathrm{for} 20 \mathrm{~min}$ at $60^{\circ} \mathrm{C}$ and centrifuged at $12000 \mathrm{rpm}$ for $10 \mathrm{~min}$. Equal amounts of supernatant and sample buffer (2\% SDS, $4 \%$ 2-mercaptoethanol, 10 $\%$ glycerol, 1 M Tris [pH 6.8], bromophenol blue) were mixed and heated at $100{ }^{\circ} \mathrm{C}$ for 10 $\min$. Ten $\mu \mathrm{l}$ proteinase-K $(2.5 \mathrm{~g} / \mathrm{l})$ solution per $50 \mu \mathrm{l}$ sample solution were added. Samples were incubated at $60^{\circ} \mathrm{C}$ for $1 \mathrm{~h}$, and then subjected to electrophoresis on sodium dodecyl sulfate-polyacrylamide gels $(12 \%$ [wt/vol] $)$ at $100 \mathrm{~V}$ for 3-4 h according to Laemmli (1970). LPS was silver stained by the method of Tsai \& Frasch (1982) using a silver stain kit (BioRad Silver Stain, Bio-Rad Laboratories, Ca.). Danish type strains (O1-O10, Va NT1-5) were used as reference strains (Sørensen \& Larsen 1986, Pedersen et al. 1993).

\section{Biochemical and physiological tests}

Strains were grown on tryptone soy broth (TSB, Difco) or tryptone soy agar (TSA, Difco) containing $1 \% \mathrm{NaCl}$. All other substrates were supplemented with $1 \% \mathrm{NaCl}$. All strains were examined for production of acid from arabinose, galactose, sorbitol and trehalose, production of indole (Kovac's), growth on TSA at $37^{\circ} \mathrm{C}$ (Cowan 1974) and hydrolysis of Tween 80 on Shotts-Waltman plates (Waltman \& Shotts 1984). 
Table 1. Distribution of $V$. anguillarum serovars among fish species in Finland.

\begin{tabular}{|c|c|c|c|c|c|c|c|c|c|c|}
\hline \multirow[b]{2}{*}{ Fish species } & \multicolumn{9}{|c|}{ Serovar $^{\mathrm{a}}$} & \multirow[b]{2}{*}{ TOTAL } \\
\hline & $\overline{\mathrm{O} 1}$ & $\mathrm{O} 2$ & $\mathrm{O} 3$ & O5 & $\mathrm{O} 8$ & O9 & $\mathrm{NT} 2^{\mathrm{b}}$ & $\mathrm{CR}^{\mathrm{c}}$ & $\mathrm{NT}^{\mathrm{d}}$ & \\
\hline Rainbow trout & 91 & & 2 & 1 & 1 & 1 & 2 & 1 & & 99 \\
\hline Atlantic salmon & & 1 & & & & & & & & 1 \\
\hline Aea trout & 1 & 1 & & & & & & & 1 & 3 \\
\hline Not known & 6 & & & & & & & & & 6 \\
\hline Total & 98 & 2 & 2 & 1 & 1 & 1 & 2 & 1 & 1 & 109 \\
\hline
\end{tabular}

${ }^{a}$ Number of bacterial strains; ${ }^{\mathrm{b}}$ Typeable with new antisera Va NT1-5; ${ }^{\mathrm{c}}$ Several cross reactions;

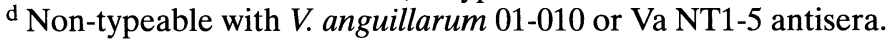

Table 2. Biochemical and physiological characteristics of Finnish V. anguillarum strains.

\begin{tabular}{|c|c|c|c|c|c|c|c|c|c|}
\hline $\begin{array}{l}\text { Serovar } \\
\text { No of strains }\end{array}$ & O1 & $\mathrm{O} 2$ & $\mathrm{O} 3$ & O5 & O8 & O9 & $\mathrm{NT} 2^{\mathrm{a}}$ & $\mathrm{CR}^{\mathrm{b}}$ & $\mathrm{NT}^{\mathrm{c}}$ \\
\hline No. of strains & 98 & 2 & 2 & 1 & 1 & 1 & 2 & 1 & 1 \\
\hline \multicolumn{10}{|l|}{ Acid from: } \\
\hline Arabinose & 67 & + & + & + & - & + & + & - & + \\
\hline Sorbitol & + & + & + & + & + & + & + & + & + \\
\hline Galactose & + & + & + & + & + & + & + & + & + \\
\hline Trehalose & - & + & + & + & + & + & + & + & + \\
\hline Indole & $97 / 2^{d}$ & $+/ 2$ & $+/ 2$ & $+/ 1$ & $+/ 1$ & $+/ 1$ & $+/ 2$ & $+/ 1$ & $+/ 0$ \\
\hline Tween $80^{e}$ & + & + & + & + & + & + & + & + & + \\
\hline Growth at $37^{\circ} \mathrm{C}$ & + & + & + & + & + & + & + & + & + \\
\hline
\end{tabular}

+: all strains positive; -: all strains negative; numbers indicate number of positive strains; ${ }^{\text {a }}$ Typeable with new antisera Va NT1-5; ${ }^{\mathrm{b}}$ Cross reactive; ${ }^{\mathrm{c}}$ Non-typeable with $V$. anguillarum $\mathrm{O} 1-\mathrm{O} 10$ or Va NT1-5 antisera; ${ }^{\mathrm{d}}$ Number of strains with strong color reaction with Kovac's indole; ${ }^{\mathrm{e}}$ Tween 80 hydrolysis.

\section{Plasmid screening}

Plasmid DNA was prepared according to Kado \& Liu (1981). Samples were run by electrophoresis on $0.8 \%$ agarose gels $(100 \mathrm{~mm} \mathrm{x}$ $100 \mathrm{~mm}$ ) in TAE-buffer ( $40 \mathrm{mM}$ Tris-acetate, 1 mM EDTA). Gels were stained with ethidium bromide $(0.5 \mathrm{~g} / \mathrm{l})$, and photographed in UV light on Polaroid film. Escherichia coli V517 (Macrina et al. 1978) and E. coli 39R861 (Threlfall et al. 1986) were used as plasmid size reference strains while $V$. anguillarum NCMB 2129 was used as a reference for a strain having the pJM1 plasmid (Conchas et al. 1991). Plasmid sizes were calculated according to the method of Rochelle et al. (1985).

\section{Susceptibility to antibiotics}

Strains were examined for susceptibility to tetracycline, oxolinic acid and trimethoprimsulfamethizol by the disc diffusion method (Casals \& Pringler 1991) using Neo-Sensitabs (Rosco A/S Diagnostica, Taastrup, Denmark).

\section{Results}

\section{Serogrouping}

Seven different serovars were found amongst the $V$. anguillarum strains (Table 1). Most of the strains belonged to serovar O1 (90\%) while serovars $\mathrm{O} 2, \mathrm{O} 3, \mathrm{O} 5, \mathrm{O} 8, \mathrm{O} 9$ and $\mathrm{Va}$ NT2 were represented by 1 or 2 strains. One 


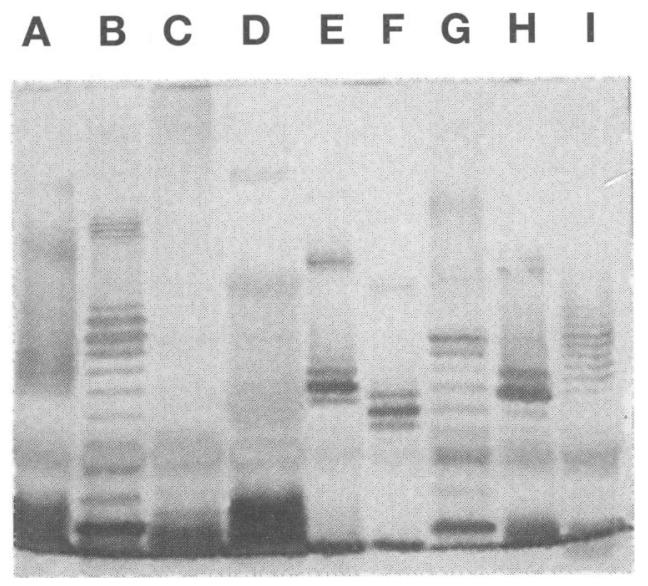

Figure 1. SDS-PAGE electrophoresis of proteinase-K prepared LPS-samples stained with silver stain from Finnish Vibrio anguillarum strains. A: Serovar O1; B: Serovar O2; C: serovar O3; D: serovar O5; E: serovar O8; F: serovar O9; G: serovar Va NT2; H: cross-reactive strain; I: non-typeable strain.

strain did not react with any of the used antisera, while another strain showed cross-reactions by reacting equally with $\mathrm{O} 8, \mathrm{O} 10, \mathrm{Va}$ NT1 and Va NT2. Both serovar O2 strains belonged to O2a subgroup.

\section{LPS profiles}

All the strains shared some common structures of LPS, but 8 distinct LPS profiles were recovered. Strains belonging to the same serovar had identical or very similar LPS profiles. The cross reacting strain had a LPS profile identical to serovar O8 (Fig. 1).

\section{Biochemical and physiological tests}

All strains produced acid from sorbitol and galactose (Table 2). Acid production from arabinose varied: $32 \%$ of the $\mathrm{O} 1$ strains and both the $\mathrm{O} 8$ and the cross reactive strains

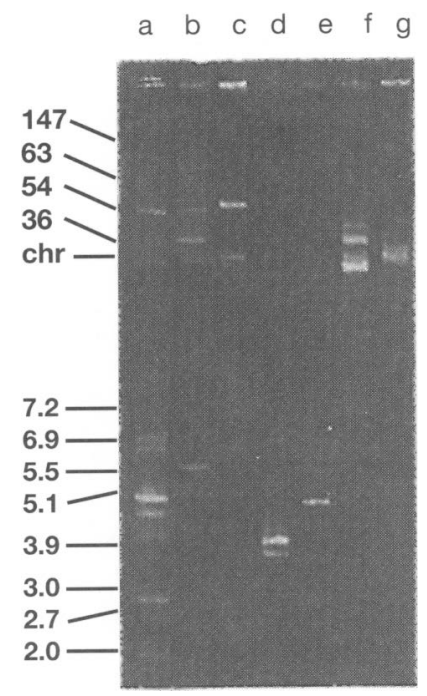

Figure 2. Different plasmid profiles of Finnish $V$. anguillarum strains isolated from diseased fish on ethidium bromide-stained $0.8 \%$ agarose gels. Lane a: E. coli V517; b: E. coli 39R861; c: serovar O1; d and e: serovar O2; f: serovar Va NT2; g: non-typeable. Numbers correspond to molecular weights in kilobases. $\mathrm{chr}=$ chromosomal-DNA.

were negative. All the strains belonging to non-O1 serovars produced acid from trehalose, while none of the $\mathrm{O} 1$ strains did. All strains, except one, were indole positive. However, there was a clear difference in the intensity of the indole reaction: 12 strains were strongly positive while the others were less intense. Almost all (10/12) of the strongly reacting strains were non-O1 strains. All strains hydrolyzed Tween 80 and grew at 37 ${ }^{\circ} \mathrm{C}$.

\section{Plasmids}

All O1 strains except one, harboured one large plasmid (65-67 kilobase [kb]) comparable in size to the pJM1 virulence plasmid. One serovar $\mathrm{O} 2$ strain had a small plasmid $(5.2 \mathrm{~kb})$ while the other had 2 small plasmids (3.9 and $4.2 \mathrm{~kb}$ ). One of the Va NT2 strains 
had 3 large plasmids (48, 36 and $30 \mathrm{~kb})$ and the non-typeable strain possessed 1 large plasmid approximately $160 \mathrm{~kb}$ (Fig. 2). No plasmids were detected in 8 of the strains.

\section{Susceptibility to antibiotics}

All strains were susceptible to oxolinic acid and trimethoprim-sulfamethizol. Except for the non-typeable strain, all strains were susceptible to tetracycline.

\section{Discussion}

The present study shows that $V$. anguillarum serovar $\mathrm{O} 1$ is predominant as a causative agent of vibriosis in Finland, as $90 \%$ of the strains belonged to serovar O1. Eleven strains belonging to non-O1 serovars included $\mathrm{O} 2$, O3, O5, O8, O9 and NT Va2 strains. Two strains remained non-typeable. LPS profiles mainly supported the sero-grouping results. The cross-reactive strain resembled the serovar O8 strain in its LPS profile and biochemical reactions. Thus the strain might belong to serovar O8.

All strains were isolated from salmonid fish, primarily rainbow trout. This may explain the predominance of serovar $\mathrm{O} 1$ in our strain collection. Common occurrence of serovar $\mathrm{O} 1$ in rainbow trout has previously been reported by Sørensen \& Larsen (1986). Several authors have reported that $V$. anguillarum $\mathrm{O} 1, \mathrm{O} 2$, and $\mathrm{O} 3$ are common fish pathogens; serovar $\mathrm{O} 1$ being associated with salmonids, sea bream, sea bass, and turbot, $\mathrm{O} 2$ causing disease especially in cod and eel, and O3 commonly occurring in eel (Pacha \& Kiehn 1969, Sørensen \& Larsen 1986, Toranzo et al. 1990, Myhr et al. 1991, Larsen et al. 1994). However, only few reports exist of the pathogenicity of the other serovars. Recently, serovars O4, O5, O6, and O8 have been isolated from diseased fish or fish larvae (Myhr et al. 1991, Pazos et al. 1992, Buchmann et al. 1993, Pazos et al. 1993), but only O4 strains have been proved to be pathogenic by experimental infection (Pazos et al. 1993). In this study the isolates belonging to serovars O5, O8, O9, and Va NT2, as well as the non-typeable and cross reactive strains, originated from different pathogenic processes. Both Va NT2 strains and the O5 strain were isolated from the kidney, which is indicative of invasive and pathogenic capacity of these bacteria. The pathogenicity of the serovar $\mathrm{O} 8$ and $\mathrm{O} 9$ strains, however, is questionable as the strains were isolated from intestine and a surface wound, respectively. The nontypeable strains were both isolated in a double infection, thus it is difficult to estimate the role of $V$. anguillarum in these cases.

Biochemically and physiologically, Finnish $V$. anguillarum strains resembled the Scandinavian control strains. All produced acid from sorbitol and galactose, hydrolysed Tween 80 and grew at $37^{\circ} \mathrm{C}$. Acid from arabinose was produced by most of them. It has previously been reported (Larsen 1990) that V. anguillarum serovar O1 strains with pJM1 plasmid do not produce acid from trehalose, while those without this plasmid do. None of the $\mathrm{O} 1$ strains in this study produced acid from trehalose, including the only strain without plasmid. This indicates that there is no connection between pJM1 plasmid and fermentation of trehalose. Current studies in our laboratory seem to support this observation (Pedersen \& Larsen, unpublished). However, all non-O1 strains did produce acid from trehalose.

Grisez et al. (1991) proposed 6 different phena for $V$. anguillarum, including a separate phenon for Scandinavian strains. Scandinavian strains were negative for indole and acid production from arabinose. Here the indole reaction was positive for all except 1 of the Finnish strains, while the arabinose reaction varied. The vast majority of the Finnish strains would therefore remain outside the 
proposed Scandinavian phenon. Grisez et al. (1991) has not included differences in the reactions between the various serovars. However, in this study there was a clear difference in the colour intensity in the indole reaction, whereas most of the $\mathrm{O} 1$ strains were weakly positive while non-O1 strains had a strong colour reaction. This, and a use of self prepared biochemical reagents instead of API 20 $\mathrm{E}$, may in part explain the difference in indole reactions between our results and those of Grisez et al. (1991).

Plasmid content of $V$. anguillarum has been widely examined (Wiik et al. 1989, Bolinches et al. 1990, Conchas et al. 1991, Larsen \& Olsen 1991, Olsen \& Larsen 1993). The existence of the pJM1 virulence plasmid coding for iron uptake in serovar $\mathrm{O} 1$ strains was recovered by Crosa et al. (1980). In the present study all the serovar $\mathrm{O} 1$ strains except 1 had a plasmid comparable in size to the pJM1. Four strains of the other serovars possessed plasmids all differing considerably from the virulence plasmid by their size. The $\mathrm{O} 2$ strains had small plasmids $(5.2,4.2$, and $3.9 \mathrm{~kb}$ ), while a nontypeable strain had a one large plasmid (160 $\mathrm{kb})$. One of the Va NT2 strains had three plasmids (48 kb, $36 \mathrm{~kb}$ and $30 \mathrm{~kb}$ ) comparable in size to those reported by Pazos et al. (1993) in some VAR strains. Connection between those VAR strains and newly created Va NT2 group is possible. The function of the plasmids, other than pJM1, is not known.

Vibriosis is one of the most common bacterial fish diseases occurring in the sea water farms in Finland (Anonymous 1991). Although most of the cultured fish populations are vaccinated before transfer to the sea, disease outbreaks still occur and fish farmers have to use medication to control the disease. According to this study, Finnish $V$. anguillarum strains are sensitive to the most commonly used anti- biotics: oxolinic acid, tetracycline, and trimethoprim-sulfonamides. However, medication poses an economical problem for fish farmers and it also influences the surrounding ecosystem. Therefore prophylactic treatment of vibriosis by vaccination is highly recommended.

Commercial vaccines used in Finland include $V$. anguillarum $\mathrm{O} 1$ and $\mathrm{O} 2$. Here $92 \%$ of the strains represented these serovars, indicating that the vaccines used should confer protection in most cases. Furthermore, with regard to the biochemical and growth properties, the Finnish strains seem to be closely related to strains isolated elsewhere in Scandinavia (Larsen 1990, Larsen \& Olsen 1991, Myhr et al. 1991, Wiik et al. 1989). Thus, it may be indicated that insufficient protection given by commercial vaccines in some fish farms results from improper vaccination rather than from vaccines themselves. In Finland, salmonid fry is usually produced in fresh water and transferred to the sea in late spring or early summer during the first year of life. There are recommendations for the minimum fish size and water temperature at the time of vaccination which is conducive for protective immunity. In practise, however, it may be difficult to adhere to these recommendations. Furthermore, the transfer to sea may be initiated prematurely after vaccination. It is difficult to receive reliable information from fish farmers regarding vaccination of fish populations, obstructing explanations for the failure in vaccination of vibriosis. Hence, it is crucial to analyze the development of immunity in the Finnish fish farming conditions and immunogenic and pathogenic properties of $V$. anguillarum strains isolated from outbreaks occurring in properly vaccinated fish populations. 


\section{Acknowledgements}

We thank Raili Schildt, National Veterinary and Food Research Institute, Helsinki and Hillevi Niiranen, Åbo Akademy, Turku, for providing strains for this study, Karl Pedersen and Nancy Noben for critical reading of the manuscript and Tarja Pohjanvirta for helpful ideas during the study. This study was supported by the Foundation of the High Technology of Savo, Finland, and by the Nordic Council of Ministers, Nordic Programme Committee for Biotechnology.

\section{References}

Anonymous: Annual Report of National Veterinary Institute, Painatuskeskus Oy, Helsinki, 1991.

Austin B, Austin DA: Vibrio anguillarum. In: Austin $B$, Austin $D A$ (eds): Bacterial fish pathogens: Disease in farmed and wild fish. Ellis Horwood Ltd, Chichester, England, 1987, 266-296.

Bolinches J, Lemos ML, Fouz B, Cambra M, Larsen $J L$, Toranzo AE: Serological relationships among Vibrio anguillarum strains. J. Aquat. Anim. Health 1990, 2, 21-29.

Buchmann K, Larsen JL, Dalsgaard I: Disease and injuries associated with mortality of hatcheryreared Baltic cod (Gadus morhua L.) larvae. Acta vet. scand. 1993, 34, 385-390.

Casals JB, Pringler N: Sensitivity testing using NeoSensitabs. Rosco Diagnostica, Taastrup, Denmark, 1991

Chart H, Trust TJ: Characterization of the surfaces antigen of the marine fish pathogens Vibrio anguillarum and Vibrio ordalii. Can. J. Microb. 1984, 30, 703-710.

Colwell RR, Grimes DJ : Vibrio diseases of marine fish populations. Helgoländer Meeresunters. 1984, 37, 265-287.

Conchas RF, Lemos ML, Barja JL, Toranzo AE: Distribution of plasmid- and chromosome mediated iron uptake system in Vibrio anguillarum strains of different origins. Appl. environ. Microbiol. 1991, 57, 2956-2962.

Cowan ST: Cowan and Steel's manual for the identification of medical bacteria. Cambridge University Press, Cambridge, England, 1974.

Crosa JH: A plasmid associated with virulence in the marine fish pathogen Vibrio anguillarum specifies an iron-sequestering system. Nature 1980, 284, 566-568.

Grisez L, Ceusters R, Ollevier F: The use of API 20E for the identification of Vibrio anguillarum and Vibrio ordalii. J. Fish Dis. 1991, 14, 359-365.

Hitchcock PJ, Brown TM: Morphological heterogeneity among Salmonella lipopolysaccharide chemotypes in silver stained polyacrylamide gels. J. Bacteriol. 1983, 154, 269-277.

Kado CI, Liu S-T: Rapid procedure for detection and isolation of large and small plasmids. J. Bacteriol. 1981, 145, 1365-1373.

Laemmli UK: Cleavage of structural proteins during the assembly of the head of bacteriophage T4. Nature 1970, 227, 680-685.

Larsen JL: Vibrio anguillarum: A comparative study of fish pathogenic, environmental, and reference strains. Acta vet. scand. 1983, 24, 456-476.

Larsen JL: Vibrio anguillarum: Characterization, ecology, and pathogenicity. Dissertation, DSR Press, Copenhagen, Denmark, 1990.

Larsen JL, Olsen JE: Occurrence of plasmids in Danish isolates of Vibrio anguillarum serovars $\mathrm{O} 1$ and $\mathrm{O} 2$ and association of plasmids with phenotypic characteristics. Appl. environ. Microbiol. 1991, 57, 2158-2163.

Larsen JL, Pedersen K, Dalsgaard I: Vibrio anguillarum serovars associated with vibriosis in fish. J. Fish Dis. 1994, 17, 259-267.

Larsen JL, Rasmussen HB, Dalsgaard I: Study of Vibrio anguillarum from different sources with emphasis on ecological properties. Appl. environ. Microbiol. 1988, 54, 2264-2267.

Macrina FL, Kopecko DJ, Jones KR, Ayers DJ, McCowen SM: A multiple plasmid-containing Escherichia coli strain: convenient source of size reference plasmid molecules. Plasmid. 1978, 1, 417-420.

Muroga K, Iida M, Matsumoto H, Nakai T: Detection of Vibrio anguillarum from water. Bull. Jap. Soc. scient. Fish. 1986, 52, 641-647.

Myhr E, Larsen JL, Lillehaug A, Gudding R, Heum $M$, Håstein $T$ : Characterization of Vibrio anguillarum and closely related species isolated from farmed fish in Norway. Appl. environ. Microbiol. 1991, 57, 2750-2757.

Pacha RE, Kiehn ED: Characterization and relatedness of marine Vibrios pathogenic to fish: physiology,serology, and epidemiology. J. Bacteriol. 1969, 100, 1242-1247.

Paterson WD, Airdrie D, Stevenson RMW, Flett DE: A different vibriosis problem in New Brunswick salmon rearing. In: Disease of fish and shellfish, $4^{\text {th }}$ EAFP International Conference, Santiago de Compostela, Spain, 1989, 85. 
Pazos F, Santos Y, Magariños B, Bandín I, Núñez S, Toranzo AE: Phenotypic characteristics and virulence of Vibrio anguillarum-related organisms. Appl. environ. Microbiol. 1993, 59, 2969-2976.

Pedersen K, Kofod H, Larsen JL: New serotypes of Vibrio anguillarum. In: Diseases of fish and shellfish. $6^{\text {th }}$ EAFP International Conference, Brest, France, 1993, 15.

Rochelle PA, Fry JC, Day MJ, Bale J: An accurate method for estimating sizes of small and large plasmids and DNA fragments by gel electrophoresis. J. Gen. Microbiol. 1985, 132, 53-59.

Sørensen UBS, Larsen JL: Serotyping of Vibrio anguillarum. Appl. environ. Microbiol. 1986, 51, 593-597.

Threlfall EJ, Rowe B, Ferguson JL, Ward LR: Characterization of plasmids conferring resistance to gentamycin and apramycin in strains of Salmonella typhimurium phage type $204 \mathrm{c}$ isolated in Britain. J. Hyg. 1986, 97, 419-426.

Toranzo AE, Barja $J L$ : A review of the taxonomy and seroepizootiology of Vibrio anguillarum, with special reference to aquaculture in the northwest of Spain. Dis. aquat. Org. 1990, 9, 73 82.

Tsai CM, Frasch CE: A sensitive silver stain for detecting lipopolysaccharides in polyacrylamide gels. Anal. Biochem. 1982, 119, 115-119.

Waltman WD, Shotts EB: A medium for the isolation of Yersinia ruckeri. Can. J. Fish Aquat. Sci. 1984, 4, 804-805.
Wiik R, Hoff KA, Andersen K, Daae FL: Relationship between plasmids and phenotypes of presumptive strains of Vibrio anguillarum isolated from different fish species. Appl. environ. Microbiol. 1989, 55, 826-831.

\section{Sammendrag}

Karakterisering af Vibrio anguillarum isoleret fra syge fisk $i$ Finland.

I alt $109 \mathrm{~V}$. anguillarum stammer isoleret fra salmonider blev karakteriseret. Stammerne var delt i 8 serovar, hvoraf serovar O1 var dominerende (90\%). Serovar O2, O3, O5, O8, O9 og en ny serovar Va NT2 var repræsenteret med enkelte stammer. To stammer kunne ikke types, en af dem krydsreagerede med flere antisera. Krydsreagerende stamme havde LPS-profil som lignede serovar O8 LPS-profil, ellers havde hver serovar en specifik LPS-profil. Alle 01 stammerne, undtagen én, havde et stort pJM1 virulens-plasmid lignende plasmid. Plasmider i forskellige størrelser blev fundet i O2, Va NT2 og i ikke typbare stammer. Bortset fra en enkelt stamme, som var resistent overfor tetracyclin, var alle stammerne sensitive for oxolinsyre, trimetoprim-sulfamethizol og tetracyklin. I deres biokemiske reaktioner lignede finske stammer skandinaviske stammer. At flertallet af de finske stammer tilhørte serovar $\mathrm{O} 1$ og $\mathrm{O} 2$ tyder på, at kommercielle vacciner anvendt i finsk akvakultur burde være effektive mod vibriose i Finland.

(Received June 3, 1994; accepted July 1, 1994)

Reprints may be requested from: Dr. S. Pelkonen, National Veterinary and Food Research Institute, Regional Laboratory of Kuopio, P.O. Box 92, SF-70211 Kuopio, Finland. 